China Perspectives

60 | july - august 2005

Varia

\title{
The Location of Manufacturing Industry and Spacial Imbalance
}

Cécile Batisse

\section{OpenEdition}

1 Journals

Édition électronique

URL : http://journals.openedition.org/chinaperspectives/502

DOI : 10.4000/chinaperspectives.502

ISSN : 1996-4617

Éditeur

Centre d'étude français sur la Chine contemporaine

\section{Édition imprimée}

Date de publication : 1 août 2005

ISSN : 2070-3449

Référence électronique

Cécile Batisse, "The Location of Manufacturing Industry and Spacial Imbalance », China Perspectives

[En ligne], 60 | july - august 2005, mis en ligne le 01 juin 2008, consulté le 28 octobre 2019. URL :

http://journals.openedition.org/chinaperspectives/502 ; DOI : 10.4000/chinaperspectives.502

Ce document a été généré automatiquement le 28 octobre 2019

(C) All rights reserved 


\title{
The Location of Manufacturing Industry and Spacial Imbalance
}

\author{
Cécile Batisse
}

1 Since the economic reforms in 1978, China has experienced average growth rates of $9 \%$ per annum according to official statistics, with peaks of over $11 \%$ in several industrial sectors. While there is some uncertainty about these rates, one cannot doubt the reality of the process of catching up which has been taking place over the last twenty-five years. The rules of the economic game have changed radically. An economy with several rates of growth has emerged, in which some dynamic regions and sectors coexist with others which are in crisis. The policy of redistribution and the public transfers seem insufficient to counterbalance the growing inequalities between coastal China, whose productive infrastructure is being modernised, and the China of the interior, which maintains an archaic structure.

2 How can this enormous territory be exploited in order to meet the needs of the population and partake in the world economy? The development strategies implemented by the Chinese authorities have varied considerably over time, affecting the geographical distribution of industrial activity inside the country. From 1949 to 1976, China's development path was inspired by Marxism-Leninism and marked by the personality of Mao Zedong. The economy was socialist, collectivist and planned. Development aimed at establishing the country's independence and the reducing social and regional inequalities. In order to exploit the national territory, this meant opening up pioneer fronts in the west and in the north, considered to be strategic regions, the construction of roads and railways, and the transfer of populations from the most densely inhabited areas. One could observe an industrial push towards the centre of the country with the policy of the Third Front and a dispersal of industry in small units in the area. Industrial structures were divided up and duplicated from one province to another.

3 Deng Xiaoping's coming to power, and the implementation of reforms at the end of the 1970s, marked a major turning point. Deng saw the priority as the modernisation of the country through controlled opening up. The reforms meant overall state control of 
production, but the state now began to call on the private sector and on the market. In order to modernise production facilities, the Chinese authorities turned to the outside world, to the technology and the capital of the industrial countries. China's transition to a market economy also led to a vast movement of decentralisation. Provincial and local leaders acquired important powers in the development of local industry, favouring the rapid proliferation of industrial units and the fragmentation of the industrial fabric. Thousands of producers, too small to be viable and manufacturing the same products, were spread all over the country. At the same time, the government favoured the development of the coastal provinces, which they saw as growth centres which, through transfers of technology, of revenues, of investment and the exploitation of their comparative advantages, would spread growth and development to the provinces of the interior.

While the combination of these different movements favoured concentration, it also had effects which varied by industrial sector and by province. What form of geographic organisation has been produced by the economic upheavals experienced by China since the implementation of reform during the 1990s? Are we witnessing an increase in concentration or a dispersal of industrial activity?

A fragmented country the size of a continent?

5 Regional balances have been upset by the growth of the coastal area and by the relative recession in the old industrial centres and the provinces of the interior. The move towards the coast is a long-term trend in the geographical distribution of activities and population. During the 1960 s and 1970s, the authorities had sought to stimulate the industrialisation of the interior by means of authoritarian administrative measures. The policy of opening up to world trade and to the logic of markets has radically changed the state of play. The contrast between the coastal area and the interior is becoming much stronger. A ring-shaped geographic differentiation is now being added over the traditional disparities between north-south and east-west. Three regional areas are becoming increasingly strongly differentiated. The prosperity of the coastal areas contrasts with the socio-economic and demographic blockages of the regions of the interior, as well as with the marginalisation of the west, which remains, however, of major strategic interest to the central government. The interior and the west, which had been privileged during the Maoist period thanks to major financial and industrial transfers, are bearing the full brunt of the restructuring of state industries which constitute their framework, while the coastal regions, by turning to world markets, are being stimulated by foreign investment and local capital ${ }^{1}$.

The coast now plays a dominant role in economic activity ${ }^{2}$. It concentrates most of the current pockets of development and the highest rates of growth ${ }^{3}$. It has a high urbanisation rate, and it is there that are located most of the cities with over a million inhabitants ${ }^{4}$. The central government, which wants to make it an engine of economic development, has assigned it three missions: acquiring the cutting-edge technology and the know-how of the developed countries, boosting exports by producing consumer goods with high added value, and modernising enterprises ${ }^{5}$. The first stage was the creation in 1980 of four Special Economic Zones (SEZ) in the provinces of Guangdong and Fujian, followed by those on the island of Hainan and the opening of 14 ports to foreign trade. Since then free zones of diverse status have proliferated. Their industrial structure is more diversified, made up of consumer goods, semi-processed goods and industrial goods ${ }^{6}$. Moreover, close to $90 \%$ of foreign direct investment (FDI) is 
concentrated on the coastal provinces, in particular the provinces of Guangdong, Fujian and Jiangsu and in Shanghai ${ }^{7}$.

7 From a geographical point of view, coastal China centres on the Gulf of Bohai (Liaoning, Hebei, Shandong, Tianjin, Peking), the Yangtse Delta (Jiangsu, Zhejiang, Fujian and Shanghai) and the southern provinces (Guangdong, Hainan, Guangxi). From an economic point of view, there appears a centre composed of three municipalities (Peking, Tianjin and Shanghai), the provinces of the Shanghai region (Jiangsu and Zhejiang), the industrialised provinces of Liaoning and Guangdong, and a periphery including less advanced provinces such as Hebei, Shandong, Fujian and the island of Hainan whose socio-economic characteristics are close to the national average. This territory, which is open to the wider world, is modernising rapidly and is the location of major projects, in particular in the domain of international transport. The second area is the central region, which constitutes a sort of intermediate, much larger China, taking in the Sichuan basin. It remains predominantly agricultural, providing most of the wheat production in the north and the rice in the south. This area also provides the coastal zone with energy (coal deposits in Shanxi, oil in northern Manchuria), and with raw materials. A few major cities, particularly Chongqing and Wuhan, which have state industrial complexes, are developing rapidly. In general terms, the share of heavy industry is higher than the national average. This state industrial structure, which exports less and is less productive, combined with a poorly trained workforce and a lower-quality economic environment, leads to productivity which is lower than that of the coastal provinces: with $36 \%$ of the country's industrial workforce, this area achieves only $28 \%$ of the value of industrial production. Nonetheless the last few years have seen the rapid development of some provinces such as Anhui, Hubei and Henan.

8 Lastly, the third area is the western part of the country, which suffers from isolation and inaccessibility and constitutes a margin, a reserve area. The characteristics of this territory are its immensity (six million square kilometres), its mountainous character, the fragmentation of its arable land, its low contribution to the national economy, its discontinuous population, the low number of its cities, and the significant presence of national minorities9. Most of the autonomous regions established by the central government between 1949 and 1965 are in this western part of China. Moreover, its growth depends on the state and on the more developed regions to which it sells its agricultural products and its raw materials in exchange for capital and technology transfers. Its industry is dominated by heavy industry, mostly made up of large state plants (oil and the metallurgy of non-ferrous metals in Gansu; oil, aluminium and electricity in Qinghai). These industrial plants are concentrated geographically, mostly in the main cities such as Shizuishan (Ningxia), Baotou (Mongolia) and Shihezi (Xinjiang). Western China has been left out of the economic opening up of the country, since its exports are minimal (about $2 \%$ of China's exports), and since, until recently, the frontiers with the Soviet Union (Xinjiang) and Vietnam (Yunnan) were closed. FDI has been limited. Finally, these provinces trade little between themselves but rather with the eastern provinces.

China lags considerably behind in terms of regional development. The differences in growth observed essentially reflect the lack of integration among the provinces themselves. Transport and communication networks are much less developed in the provinces of the interior than on the coast. The government has launched a policy of opening up the interior of the country, in which transport infrastructure plays an 
essential part: enlargement of the road and rail network, construction of routes from east to west, of regional routes, and of routes leading to the outside world. Examples are the railways linking Xi'an to Hefei and Xi'an to Nanjing, and the motorways from Peking to Zuhai and from Peking to Chengde. This spacial segmentation is accentuated by differing commercial rules and conditions, and by the way in which public policies are applied.

The evolution in the geographical concentration of industrial activities and in the specialisation of the provinces thus stems both from overall development strategy and from the territory's geographical reality. What changes have appeared in the location of industrial activity? What do we learn from analyses of the rates of industrial concentration and specialisation of the Chinese provinces ${ }^{10}$ ?

Specialisation of the provinces and location of industry

Relations between geographical area and economic activity can be understood through two complementary approaches, by province and by sector. In the first case, for each province, we study the distribution of economic activity among the various sectors; sectoral concentration measures each province's degree of specialisation. In the second case, for each sector, we study its location in all the provinces; geographical concentration is a measure of the distribution of a sector on the scale of the country as a whole.

1. The degree of industrial specialisation across provinces in 1988

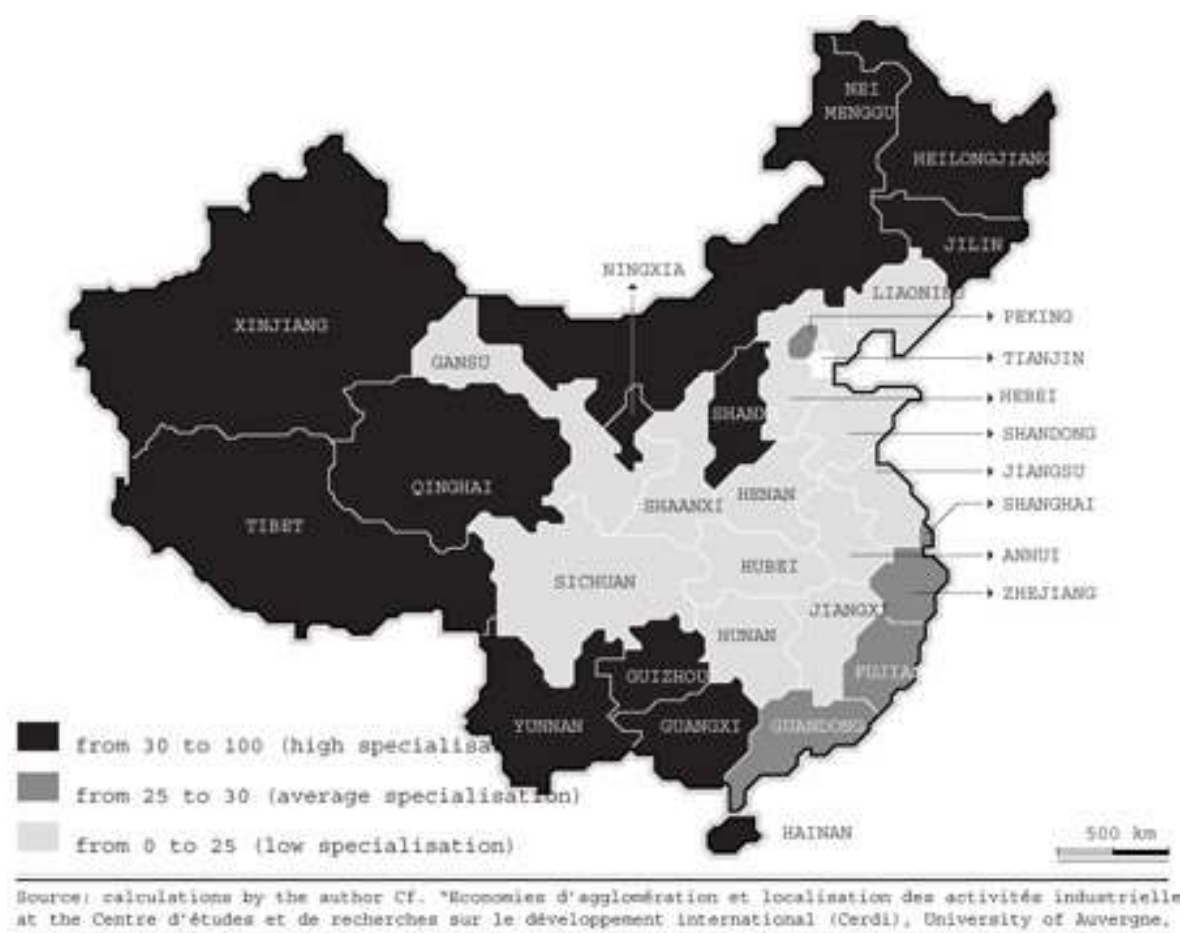

The sectoral concentration of the provinces

The industrial specialisation of the provinces increased between 1988 and 1997. This trend can be observed just about everywhere ${ }^{11}$. This evolution took place in stages. The period 1988-1989 was marked by an average decline in specialisation. This decline was particularly marked in provinces such as Anhui, Jiangxi, Inner Mongolia, Xinjiang and Gansu. During this period, China went through major economic turbulence which affected all sectors, coupled with domestic political problems (the events of 1989). From 
1989 to 1992, there was an average increase in specialisation. This increase was due to the provinces of Jilin, Gansu, Henan, Tianjin and Peking. Specialisation increased between 1992 and 1994 (Qinghai, Sichuan, Gansu, Xinjiang, Hebei). Finally, there was a slowing of specialisation between 1994 and 1997 (see maps 1 and 2).

2. The degree of industrial specialisation across provinces in 1997

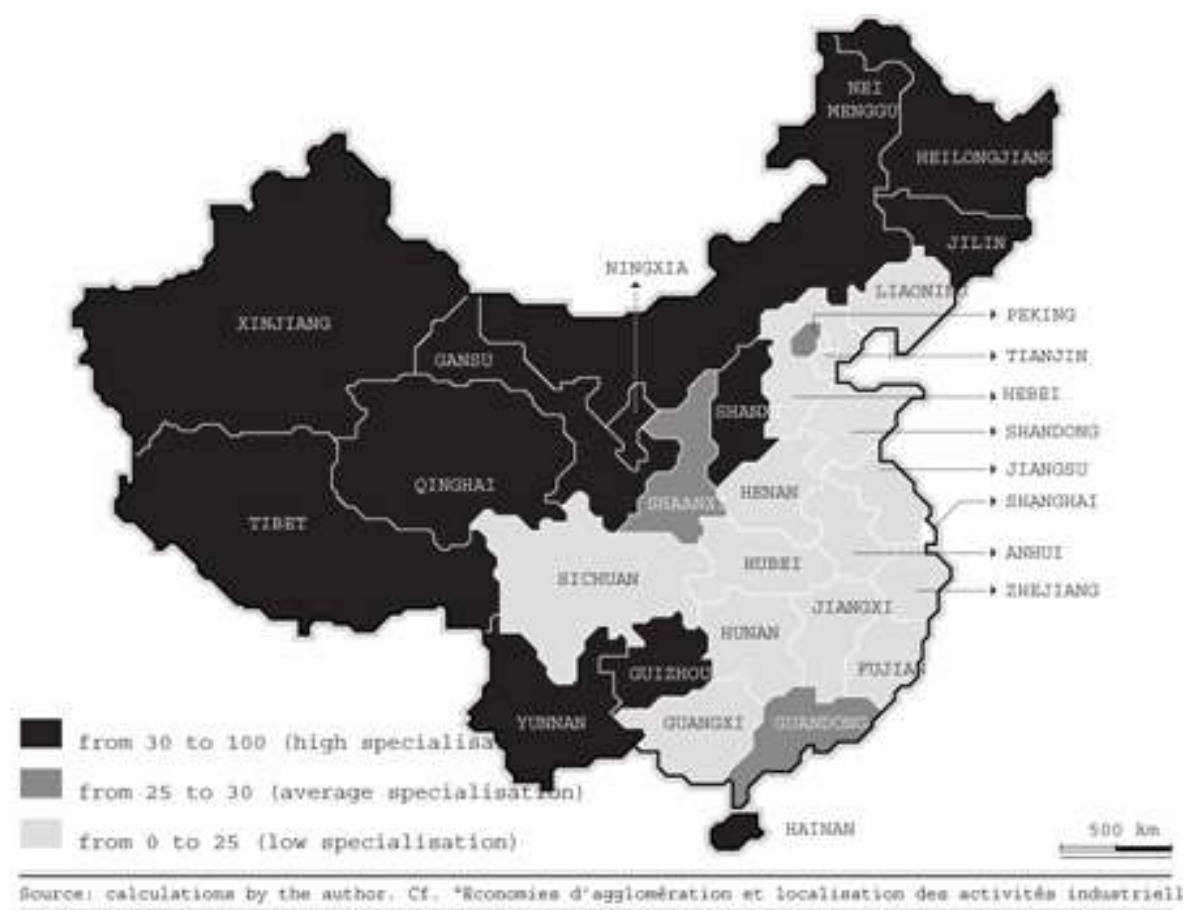

The provinces of the west and of the north appear, at the beginning of this period, as the most specialised, followed by the coastal provinces (the island of Hainan is an exception) and the central provinces. Among the coastal provinces, those in the south have a higher level of specialisation than those of the east where state heavy industries are concentrated (Tianjin, Hebei, Liaoning, Shandong). During the period under consideration, it appears that the inaccessible and poorer western provinces were those which experienced the most rapid growth in their degree of manufacturing specialisation. Moreover, while the manufacturing specialisation of the provinces in the west and in the centre grew from 1989 to 1997 (except for a slight slowdown in the western region between 1991 and 1992), the coastal provinces experienced a decline in their specialisation from $1994^{12}$.

Coupled with the state's disengagement from the allocation and distribution of goods, as well as from the fixing of prices, the promotion of international trade and investment made possible the concentration of activity and the specialisation of the provinces. While the success of the reforms promoting international trade is universally acknowledged, there is a gap between the provinces of the coast and those of the interior. While the coastal provinces are experiencing a movement away from specialisation and towards diversification, mainly stemming from the period of the reforms, the industrial specialisation of the provinces of the interior is increasing and their industrial structure is concentrating on a few big traditional sectors, legacies of the time of central planning ${ }^{13}$. One possible explanation for this apparently counterintuitive evolution is the existence of a Chinese particularity, the development of 
provincial and local protectionist tendencies. Thus the domestic market is increasingly fragmented, protected by a plethora of local measures, ranging from simple road blocks to technical norms ${ }^{14}$. Several studies show that this phenomenon is particular widespread in the western and central provinces, which protect certain sectors in which they do not necessarily have any competitive advantage. A direct consequence of this is the increase in the presence of unproductive sectors in these provinces. In contrast, the lowering of levels of specialisation in the coastal provinces can be linked to the abolition of these barriers and to the greater participation of these provinces in domestic and international trade. This is the hypothesis advanced by Barry Naughton ${ }^{15}$, according to which the apparent reduction in specialisation after opening up is merely the consequence of an initial movement of reorganisation of the industrial structure between provinces.

The provinces are thus affected differently according to whether they are situated in the centre or on the periphery ${ }^{16}$ (see map 2). Generally speaking, the most industrialised provinces, where all sectors are represented, contrast with the "slow" provinces, where the dominance of certain activities, particularly those involving raw materials and products with low added value, is growing.

What are the industrial sectors in the provinces?

Because of the size of the provinces, the underdeveloped state of communications, and the regional protectionism established under Mao Zedong, which was followed up in the 1980s by the rise in the economic prerogatives of local and provincial authorities, most industrial sectors are represented in all the provinces. Thus for example, 28 provinces produce coal, 29 produce medical and pharmaceutical products, etc. ${ }^{17}$. However the degree of industrial concentration varies.

The most specialised provinces are Xinjiang, Yunnan, Heilongjiang, the island of Hainan, and Shanxi. The common characteristic of all these provinces is that they possess abundant natural resources, while the processing industry is relatively undeveloped there.

18 The industrial structure of Xinjiang is dominated by the exploitation of hydrocarbons, with petrol amounting to $44 \%$ of its industrial added value. In 2003, China overtook Japan to become the world's second largest oil consumer after the United States, with demand reaching 5.9 million barrels a day and expected to double by 2025. In comparison its production is only 3.4 million barrels a day. Xinjiang's potential is still far from being fully exploited, and its exploitation is concentrated geographically around the provincial capital of Urumqi. Prospecting and exploitation efforts are also being carried out in the southern part of the province.

Yunnan is specialised in the tobacco industry, which represents over $60 \%$ of the province's added value. The industrialisation of this province is not far advanced and remains centred on underdeveloped activities with low added value.

Mining is the source of wealth in Heilongjiang (particularly iron and coal). This province, where many state enterprises are to be found, remains one of the most industrialised in the country. The development of heavy industry has led to a surfeit of certain industrial sectors such as wood, bamboo and wood products, mining industries, chemicals, and basic metallurgy. Like the other provinces of Manchuria (Liaoning and Jilin), Heilongjiang is a stricken province and is experiencing a crisis of its heavy industry, dominated by state enterprises. 

opening up. After acquiring the status of a province in 1988, the island set up a market economy turned towards exports, and encouraged foreign investors to set up plants on its territory. Hainan therefore mostly favoured light industry. The importance of refining needs to be emphasised also, in direct relation with the province's offshore hydrocarbon reserves (a major project is to supply Guangdong with natural gas from Hainan). The Yingehai and Qiong basins as well as that of the Zhu river are endowed with 5,000 billion cubic metres of natural gas reserves.

Lastly, Shanxi enjoys rich underground resources, since the three main coal mining cities in China are situated in this province (Yangquan, Changzhi and Datong). While the coal reserves are large, they only began to be used after the proclamation of the People's Republic, and were not really exploited until after 1982, when the government created an energy production base centred on Shanxi and including part of Shaanxi and of Inner Mongolia ${ }^{18}$. The state, with the support of foreign capital, is carrying out major investment in this region, seeking to make it the main supplier of coal and electricity to the coastal zone. Besides its mining activities, Shanxi is also undergoing specialisation in important heavy industries linked to the basic metallurgy sectors (15\% of added value is created in the exploitation of ferrous metals), the chemical industry (6\%), and ordinary machine tools. This concentration on three or four sectors is a configuration shared by the provinces of Ningxia, Jilin, Qinghai and Inner Mongolia.

We can contrast this group with the provinces with little mining activity, which are more focused on the processing of agricultural and intermediate products, which is to say Peking, Tianjin, Shanghai, Zhejiang, and Guangdong on the coast, and Hubei in the interior.

The geographical concentration of industrial sectors

24

Analysis of the rates of concentration shows very different evolutions according to the industrial sector concerned. We have divided them into five distinct groups by levels and by evolution in levels of concentration. We examine the ten most concentrated sectors in 1988, and then divide this group between the sectors which still showed high concentration in 1997 and those which no longer form part of this group. In the same way, we examine the ten least concentrated sectors in 1988 and divide this group into those which show the lowest levels of concentration in 1997, and those which are no longer part of this group. Finally the sectors which do not correspond to any of these criteria make up a residual group (see Table 3 ). 
3. Sectors by evolution of concentration

\begin{tabular}{|c|c|}
\hline Cogroontrated asctors vhuch haye renta inod & 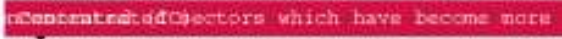 \\
\hline Extraction and by-producta of ot 1 and ga: & Wood, bamboo and wood product:s \\
\hline \multicolumn{2}{|l|}{ Transportation of wood and bamboo } \\
\hline \multicolumn{2}{|l|}{ Blectronica and telecommunicatione } \\
\hline \multicolumn{2}{|l|}{ Tobacco } \\
\hline \multicolumn{2}{|l|}{ Nining and by-praducts of coal } \\
\hline \multicolumn{2}{|l|}{ Cultural and sporting goods } \\
\hline \multicolumn{2}{|l|}{ Perrous metala } \\
\hline \multicolumn{2}{|l|}{ office equipnent } \\
\hline \multicolumn{2}{|l|}{ Extraction of ferrous thetale } \\
\hline Diepersed sectora which have beconte thore & 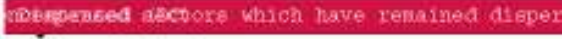 \\
\hline Paper and paper artieles & Poodetuffe industry \\
\hline \multirow[t]{7}{*}{ Rubber } & Notal products \\
\hline & Chenical producta \\
\hline & Pharmaceutical and nedical producta \\
\hline & Printed articles \\
\hline & Furniekings \\
\hline & ordinary machino tools \\
\hline & Non-matalie mineral product: \\
\hline \multicolumn{2}{|l|}{ Prosidual graup (R) } \\
\hline Drinks & Plasties \\
\hline Chenical tibres & Production and supply of energy, pressure = \\
\hline clothing & Production and aupply of water \\
\hline Eleetric equiptnent and machinery & Textiles \\
\hline Leather and leather articles & Tranaport equipment: \\
\hline
\end{tabular}

Nine sectors (CC) were among the most highly concentrated in 1988 and continued to be so in 1997. Among them, those with the strongest concentration of activity remain firstly the extraction and by-products of petroleum (lubricants) and the extraction and by-products of natural gas, the transport of wood and bamboo, and ferrous and nonferrous metals. For these sectors the proximity of natural resources is essential, and they were developed during the first two phases of Chinese industrial development. These sectors are highly geographically dependent for their production. The oil industry for example in highly concentrated in the northwest. The main oil fields are in the autonomous province of Xinjiang and the province of Qinghai, but also in Shandong and, in the northeast, Heilongjiang and Liaoning. The exploitation of natural gas is concentrated in Sichuan. Secondly, the high geographical concentration of the tobacco industry in Yunnan has undoubtedly facilitated reform and the achievement of economies of scale in this sector, carried out by central government and the provincial authorities. Lastly one also finds sectors which are close to the end markets where consumer choice and competition have led to a selection of enterprises and a process of rapid concentration. This is particularly the case for cultural and sporting goods, office equipment, consumer electronics and telecommunications. In this last sector with a high technology content, the gap has grown between the provinces which dominate the market and the marginal provinces.

Some sectors (DC) which were among the most dispersed have experienced an increase in geographical concentration. Paper-making activity has increased, particularly in Jiangsu, Shandong, Shanghai and Guangdong. The rubberised products sector remains geographically dispersed, but has increased in some regions such Shanghai and Shandong. 
The sectors (CD) which were initially very concentrated, and which became more dispersed over the period 1988-1997 are few in number: wood, bamboo and wood products. This sector was initially concentrated in Heilongjiang and then saw its activity increase in other provinces, such as those of Fujian and Jiangxi. Exploitation has in fact spread from the northeast to the forests of the southeast.

Eight sectors (DD) were among the least concentrated in 1988 and were still so in 1997. These are in particular foodstuffs, metal products, chemicals, pharmaceutical and medical products, printing and furniture. The low concentration of these sectors can be partly explained by a weakness in competition mechanisms which keeps inefficient enterprises on the market. Moreover, the initial geographical dispersion of these industries has allowed local protectionism full rein. Until recently, local governments have been able to prefer subsidising less productive enterprises rather than relinquish having them on their territory. Local protectionism and the lowering of entry barriers in some sectors of production have led to a rapid growth in the number of enterprises operating in these sectors ${ }^{19}$.

The residual group (R) includes ten sectors which had an average level of concentration in 1988. Most remained in this group until 1997. However, some sectors have experienced changes in their levels of geographical concentration, accounted for by the factors mentioned above. Thus the clothing sector was among the ten most concentrated sectors in 1997, reinforcing its position in Guangdong in particular. In contrast, the drinks sector and the production and supply of energy have experienced a dispersion of their activity over the period, since they appear in 1997 among the ten most dispersed sectors.

In terms of industrial structure, most of the Chinese provinces tended to diverge at the end of the 1980s and the beginning of the 1990s; but from the mid 1990s, this divergence tended to slow down. There was a gap between the coastal provinces and those of the interior. It is highly probable that the continuation of reforms and of opening up will reinforce the current trend, and that sectors where concentration was low, or even negative, will experience a more intense competitive process which will select the most efficient enterprises and lead to a greater process of concentration. Accession to the World Trade Organisation in particular makes necessary a number of legislative and regulatory changes at national and of course at local levels (the right to competition, property rights, reorganisation of state enterprises, lifting of tariff and non-tariff barriers).

31 Moreover, China is the country with the highest pollution levels in the world. Excessive exploitation of natural resources and the degradation of environmental conditions could have negative effects on production factors (arable land and the workforce). The Chinese authorities are therefore in the process of rethinking modes of production, which entails changes in the geographical organisation of industrial activities.

Translated from the French original by Michael Black 


\section{NOTES}

1. Françoise Lemoine, L'Economie chinoise (The Chinese Economy), Paris, La Découverte, 2003.

2. The coastal (or eastern) zones are made up of ten provinces and of three municipalities which are directly controlled by the central government. These are municipalities of Peking, Tianjin and Shanghai, and the provinces of Liaoning, Hebei, Shandong, Jiangsu, Zhejiang, Fujian, Guangdong, Guangxi and Hainan.

3. The provinces of Jiangsu, Shandong, Guangdong, Liaoning and Zhejiang made up, in $2003,39 \%$ of national industrial production and $35 \%$ of the added value of Chinese enterprises as a whole (China Statistical Yearbook, National Bureau of Statistics, Peking, 2004). During the Maoist period, Liaoning was one of the main beneficiaries of state investment in heavy industry; the other coastal provinces mainly industrialised during the period of the reforms.

4. Wei Yehua Dennis, Regional Development in China: States, Globalization and Inequality, London, Routledge, 2000.

5. Yang Dali, Beyond Beijing: Liberalization and the Regions in China, London, Routledge, 1997.

6. Chen Yi and Sylvie Démurger, "Croissance de la productivité dans l'industrie manufacturière chinoise : le rôle de l'investissement direct étranger" (Productivity growth in Chinese manufacturing industry: the role of foreign direct investment), Economie internationale, No. 92, 2002, pp. 135-168.

7. Cf. Françoise Lemoine, "FDI and the Opening Up of China's Economy", Document de travail, 00-11, June, Centre d'études prospectives et d'informations internationales (Cepii), Paris, 2000; François Gipouloux; "Les effets spatiaux de l'investissement direct étranger (IDE) en Chine : intégration ou désintégration?" (The geographical effects of foreign direct investment [FDI] in China: integration or disintegration?), Géoconfluences, on the site www.ens-lsh.fr/geoconfluence/.

8. Central China is composed of the provinces of Shanxi, Henan, Anhui, Hubei, Hunan, Heilongjiang, Jilin and Jiangxi.

9. It is composed of Yunnan, Tibet, Qinghai, Shaanxi, Gansu, Sichuan, Guizhou, Ningxia, Inner Mongolia and Xinjiang.

10. We quote here some of the findings of our doctoral thesis in economics: "Economies d'agglomération et localisation des activités industrielles en Chine" (The economies of built-up areas and the location of industrial activity in China), prepared and presented at the Centre d'études et de recherches sur le développement international (Cerdi)

[Centre for Study and Research on International Development], University of Auvergne, 2003.

11. In only six provinces did the level of specialisation decline: Tibet, Anhui, Hubei, Liaoning, Zhejiang and Hainan.

12. These figures are however subject to an excessive level of aggregation. More precise statistical nomenclature would make it possible to show the diversity of situations and to analyse evolution at the level of cities and products rather than on the scale of provinces and sectors. 
13. Cécile Batisse, "Dynamic Externalities and Local Growth: A Panel Data Analysis Applied to Chinese Provinces", China Economic Review, Vol. 13, No. 2/3, 2002, pp. 231-251.

14. Cf. Sandra Poncet, "The fragmentation of the Chinese domestic market", China Perspectives, No. 55, September-October 2004, pp. 11-20.

15. Barry Naughton, "How much can regional integration do to unify China's markets?", in Nicholas Hope, Dennis Yang and Mu Yang Li (eds.), How far across the river? Chinese Policy Reform at the Millenium, Stanford, Stanford University Press, 2003, pp. 204-232.

16. Dupuch, Jennequin and Mouhoud find a similar tendency in their study of specialisation trends within the European Union. They show in particular that the less advanced member states (Portugal and Greece) seem to be the most specialised, their specialisation involving activities with high natural resource and labour intensities. Dupuch Sébastien, Jennequin Hugues and Mouhoud El Mouhoub, "Intégration européenne, élargissement aux pays d'Europe centrale et orientale et économie géographique" (European integration, enlargement to the countries of Central and Eastern Europe and geographical economics) Région et Développement, Vol. 13, 2001, pp. $125-162$.

17. China has 21 provinces, five autonomous regions and four municipalities directly administered by the central government-comparable to provinces-since 1997, when the municipality of Chongqing was raised to the rank of a province.

18. Jean-Pierre Larivière and Jean-Pierre Marchand, Géographie de la Chine (Geography of China), Paris, Armand Colin, 1999.

19. Jean-François Huchet, "Concentration and the Emergence of Corporate Groups in Chinese Industry", China Perspectives, No. 23, MayJune 1999, pp. 4-17.

\section{RÉSUMÉS}

Opening up and economic development are usually accompanied by geographical concentration and increased specialisation of activities. What is the situation in China? Peking's accession to the World Trade Organisation (WTO) has had several effects. In particular, trade liberalisation has mainly benefited the coastal provinces, which have a diversified industrial infrastructure, and is likely to increase the already significant disparities between the coast and the interior, where activity is more concentrated on a few major traditional sectors. In order to better understand the changes to come, this article describes the evolution in the location of industrial activities and of specialisation in the Chinese provinces from the end of the 1980 s. 